\title{
Spontaneous hybridisation between vegetable crops and weeds. 1: Garden radish (Raphanus sativus L.) and wild mustard (Sinapis arvensis L.)
}

\author{
Frédérique Eber ${ }^{\mathrm{a}}$, Richard Boucherie ${ }^{\mathrm{b}}$, Louis-Marie Broucqsault ${ }^{\mathrm{b}}$, \\ Yves Bouchet ${ }^{\mathrm{c}}$, Anne-Marie Chèvre ${ }^{\mathrm{a} *}$ \\ a Station d'amélioration des plantes, Inra BP29, 35653 Le Rheu, France \\ ${ }^{\mathrm{b}}$ Ferme expérimentale Marcellas FNAMS, 26800 Étoile, France \\ c 'Le Verger' FNAMS, 49800 Brain sur l'Authion, France
}

(Received 7 April 1998; accepted 7 August 1998)

\begin{abstract}
In order to assess the risk of commercial F1 hybrid seed contamination due to outcrossing on male sterile radish line pollinated by wild mustard, two isolated field experiments were performed in the presence or absence of garden radish pollen. Additionally, spontaneous wild radish plants were observed under $200 \mathrm{~m}$ away from both fields. Seeds were harvested on the female radish line and sieved. Isozyme analyses combined with cytogenetical characterisation revealed that morphological observations were not efficient enough to distinguish the interspecific hybrids among the seedlings obtained. The radish-wild mustard interspecific hybrid production was higher without than with radish pollen competition: 42 and 3 interspecific hybrid seeds per 1000 seeds were observed, respectively. Numerous cultivated-wild radish hybrids were observed from the two experiments without and with radish pollinator: 551 and 144 per 1000 seeds, respectively. Sieving seems to be efficient in preventing the commercialisation of cultivated radish-wild mustard hybrids. (@ Inra/Elsevier, Paris.)
\end{abstract}

\section{Brassiceae / interspecific hybridisation / morphology / isozyme / meiotic behaviour}

Résumé - Hybridation spontanée entre plantes maraîchères et adventices : 1. Radis (Raphanus sativus L.) et moutarde des champs (Sinapis arvensis L.). Pour évaluer les risques de contamination des lots de semences dus à une pollinisation des lignées mâles stériles de radis par la moutarde des champs, deux expérimentations ont été réalisées en

Communicated by C.F. Quiros (Davis, USA)

\footnotetext{
* Correspondence and reprints

E-mail: chevre@lerheu.rennes.inra.fr)
} 
présence ou en l'absence de pollinisateurs radis. De plus des ravenelles ont été observées à environ $200 \mathrm{~m}$ des deux champs. Les graines ont été récoltées sur la lignée de radis femelle et tamisées. Les analyses isoenzymatiques combinées à des observations cytogénétiques ont révélé que la seule observation morphologique des plantules était insuffisante pour identifier les hybrides interspécifiques. La production d'hybrides interspécifiques radis-moutarde des champs est plus élevée en absence ( 42 hybrides/ 1000 graines) qu'en présence ( 3 hybrides $/ 1000$ graines) de pollen de radis. En ce qui concerne les hybrides radis-ravenelle, 551 ont été obtenus pour 1000 graines récoltées dans l'essai sans compétition pollinique et 144 dans l'essai avec compétition pollinique. Le tamisage est efficace pour limiter la commercialisation d'hybrides radis-moutarde des champs. (@) Inra/Elsevier, Paris.)

\section{Brassiceae / hybridation interspécifique / morphologie / isoenzymes / comportement méiotique}

\section{INTRODUCTION}

Seed contamination must be very low to be acceptable for the production of pure line or Fl varieties of garden radish (Raphanus sativus, $2 \mathrm{n}=$ 18, RsRs); for example, in France the limit is less than $0.1 \%$.

Two main factors can be responsible for seed contamination. The first one is pollination by cultivated radish plants growing in a neighbouring field. It has been shown that pollen dispersal can reach at least $1000 \mathrm{~m}$ [6]. The isolation distance required for commercial seed production is $1500 \mathrm{~m}$. The second factor is the presence in the cultivated areas, ditches or fallow, of many cruciferous weedy relatives with the same flowering period as the crop. They can contaminate the purity of commercial seeds by hybridisation. Among the weeds, one of the most frequent is wild radish (Raphanus raphanistrum, $2 \mathrm{n}=18, \mathrm{RrRr}$ ) for which the possibility of intercrosses with garden radish has already been demonstrated under natural conditions [9]. Another common weed is wild mustard (Sinapis arvensis, $2 \mathrm{n}=18$, SarSar), widespread in the radish seed production region. Interspecific hybrids involving $R$. sativus and $S$. arvensis were produced for phylogenetic and cytogenetic studies by Mizushima [7]. Chopinet [3] and Turesson and Nordenskiold [11] described the interspecific hybrids obtained by crossing a tetraploid radish with wild mustard. However, no spontaneous hybridisation was reported between these two species under field conditions.

The present experiment was requested by seed producers using a male sterile garden radish line carrying the Ogura cytoplasm [8] for the production of F1 hybrid varieties. The aim of the study was to determine whether spontaneous interspecific hybridisation between $R$. sativus and $S$. arvensis could occur in the presence or absence of pollen competition. These studies were performed with a special emphasis on interspecific hybrid characterisation. Usually, to determine the purity of a commercial garden radish seed variety, five samples of 2000 seeds are sown and screened for swollen roots (actually the upper part of the tap root and the hypocotyl). Here, this criterion as well as biochemical and cytological analyses were used to characterise the material.

\section{MATERIALS AND METHODS}

\subsection{Material}

The female garden radish line (Raphanus sativus, $2 \mathrm{n}=18$, RsRs), a male sterile with Ogura cytoplasm, and a male garden radish line were provided by Vilmorin (France). The two populations of wild mustard (Sinapis arvensis, $2 \mathrm{n}=18$, SarSar) were collected by Labosem and Plichet (France). As control, two wild radish populations from Inra Rennes and Dijon were used. 


\subsection{Field experiments}

Field experiments were set up in two different isolated trials. In the first one (1a), the garden radish female parent and the wild mustard were arranged in plots of three rows $5 \mathrm{~m}$ long $(0.50 \mathrm{~m}$ between two rows) in a ratio $1: 1$ at a density of 45 plants per $\mathrm{m}^{2}$. This trial had six replicates of the two parental alternating plots $\left(90 \mathrm{~m}^{2}\right)$. In the second trial $(\mathrm{lb})$, each plot had the same design as previously described, but the garden radish female parent was surrounded on one side by the wild mustard plot and on the other side by the garden radish male parent plot. This trial had six replicates of the three parental alternating plots $\left(135 \mathrm{~m}^{2}\right)$. In both trials, a few spontaneous wild radish (Raphanus raphanistrum, $2 \mathrm{n}=18, \mathrm{RrRr}$ ) plants (3-10) were observed less than $200 \mathrm{~m}$ away.

The overlapping flowering period was estimated by counting on different dates the number of opened flowers on 15 plants of garden radish (female for 1a, male and female for $1 \mathrm{~b}$ ) in three replicates, and on six plants of wild mustard (for $1 \mathrm{a}$ and $\mathrm{lb}$ ) in one replicate.

To assess the seed set on the male sterile garden radish parent, two types of observations were performed. According to the observations usually made in a normal field seed production on a pure line of garden radish, the number of pods per 100 flowers was calculated by counting all the flowers and all the pods formed on six plants ( 1 plant/replicate) in trial $1 \mathrm{~b}$; the aim was to obtain a global assessment of pod set on the whole plant, covering all the flowering period. Because of the absence of radish pollinator in trial la, the sample was multiplied by two, i.e. 12 plants (2 plants/replicate). Second, the average number of seeds per pod was calculated from seed counts obtained in the pods previously observed.

In the two trials all the male sterile garden radish plots were harvested. As commercial seed size ranges from 2.4 to $2.8 \mathrm{~mm}$, three grading groups were obtained by sieving $600 \mathrm{~g}$ of the total harvest from each trial: seeds $>2.8 \mathrm{~mm}, 2.4<$ seeds $<2.8 \mathrm{~mm}$ and seeds $<2.4 \mathrm{~mm}$. The 1000 seed weight was established in order to calculate the seed number in each grading group.

\subsection{Characterisation of harvested seeds}

\subsubsection{Morphological observations}

Morphological observatons were performed on three to four leaf plantlets in the greenhouse. The presence or the absence of a swollen root was scored on 107,80 and 72 plants in the la trial, on 79,80 and 158 plants in the $1 \mathrm{~b}$ trial, for the seeds $>2.8 \mathrm{~mm}, 2.4<$ seeds $<2.8 \mathrm{~mm}$ and seeds $<2.4 \mathrm{~mm}$, respectively.

\subsubsection{Isozyme analyses}

For isozyme analyses, young leaves were crushed in Tris $\mathrm{HCl} 0.1 \mathrm{M}$ extraction buffer $\mathrm{pH} \mathrm{7.8,} \mathrm{containing} 1 \%$ $w / v$ reduced glutathion. Ten isoenzymatic systems were revealed using the standard starch-electrophoresis method: triosephosphate isomerase (TPI), 6-phosphogluconate dehydrogenase (6-PGD), phosphoglucoisomerase (PGI), leucine aminopeptidase (LAP), aconitase (ACO), phosphoglucomutase (PGM), glutamate oxaloacetate transaminase (GOT), shikimate dehydrogenase (SDH), isocitrate dehydrogenase (IDH) and malate dehydrogenase (MDH). The six first isozyme systems (TPI, 6-PGD, PGI, LAP, ACO and PGM) were studied by the method described by Chèvre et al. [2]. GOT was separated on a Tris-citrate/lithium borate buffer $\mathrm{pH} 8.3$ and SDH on a histidine/Tris-citrate buffer $\mathrm{pH} 7.0$ [10]. IDH and MDH system analyses were performed on a morpholine citrate $\mathrm{pH}$ 6.1 gel [2]. The composition of the staining solutions for GOT, SDH, IDH and MDH systems was reported by Vallejos [12].

\subsubsection{Cytological studies}

For cytological studies, floral buds were fixed in Carnoy's solution and pollen mother cells stained as described by Eber et al. [4]. The M I stage of meiosis was observed in order to establish the meiotic behaviour.

\section{RESULTS}

\subsection{Field experiments}

In our natural conditions, wild mustard populations flower from March to September and so we attempted in our field experiments to have an overlapping flowering period between the two species studied. It was assessed that wild mustard flowered earlier than the two garden radish lines, in both trials (figure 1). However, Sinapis pollen was produced during the main part of the garden radish flowering period. In the $1 \mathrm{~b}$ trial, a difference was 

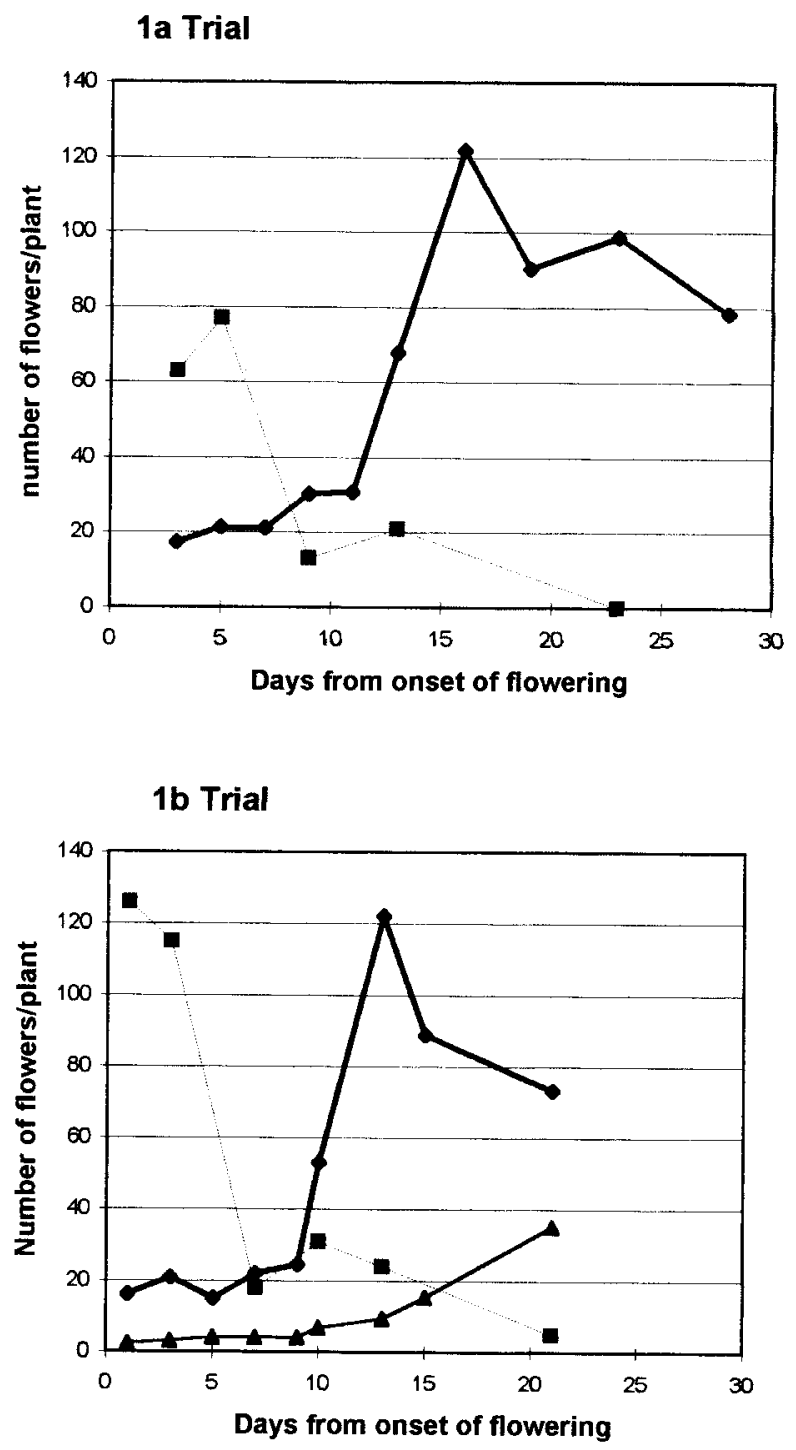

Figure 1. Number of opened flowers/plant along the flowering period in the trials 1 a (without pollen competition) and $1 \mathrm{~b}$ (with pollen competition) for the male sterile $(-\rightarrow-)$ and the male fertile ( $-\mathbf{A}_{-}$) garden radish, and for wild mustard (--- - - ). recorded between the two radish line flowering periods. The female male sterile line started flowering 9 days before the male fertile line.

The seed set parameters are given in table I. The flower number per plant of the male sterile radish line was three times higher in the la trial than in 1b. However, because of the absence of radish pollinator in trial 1a, pod number and seed number per 100 flowers were 10 and 100 times lower in the 1 a than in the $1 b$ trial, respectively.

\subsection{Morphological characterisation}

Plants from seed samples of each of the three grading groups were analysed. Overall, $50.6 \%$ of seedlings from trial $1 \mathrm{a}$ and $26.8 \%$ of seedlings from trial $1 \mathrm{~b}$ did not have the swollen hypocotyl typical of the garden radish phenotype (figure 2).

More precisely, in the 1a trial, $75 \%$ of plants grown from the smallest seeds $(<2.4 \mathrm{~mm})$ did not have a swollen root, whereas abnormal root development was observed on 22.5 and $55.1 \%$ of the plants in the commercial grading $(2.4<$ seeds $<2.8 \mathrm{~mm})$ and the biggest $(>2.8 \mathrm{~mm})$ seed size groups, respectively.

In the $1 \mathrm{~b}$ trial, in the smallest, the commercial and the biggest grading groups, the percentages of plants without swollen roots were 38.6, 16.2 and $13.9 \%$, respectively.

\subsection{Isozyme characterisation}

Ten isoenzymatic systems (TPI, 6-PGD, PGI, LAP, ACO, PGM, GOT, SDH, IDH and MDH)

Table I. Seed production of the male sterile radish line.

\begin{tabular}{cccccc}
\hline Trial & $\begin{array}{c}\text { Flower number } \\
\text { per plant }\end{array}$ & $\begin{array}{c}\text { Pod number } \\
\text { per plant }\end{array}$ & $\begin{array}{c}\text { Pod number } \\
\text { per 100 flowers }\end{array}$ & $\begin{array}{c}\text { Seed number } \\
\text { per pod }\end{array}$ & $\begin{array}{c}\text { Seed number } \\
\text { per 100 flowers }\end{array}$ \\
\hline $1 \mathrm{a}$ & 3468 & 96 & 2.8 & 0.45 & 1.2 \\
$\mathrm{lb}$ & 1046 & 373 & 35.6 & 3.61 & 128.7 \\
\hline
\end{tabular}


were studied on ten plants of male and female garden radish, 20 plants of two wild mustard populations and 20 plants of wild radish. The comparison of the three different species, taking into account the allelic variation at each locus, allowed us to choose the malate dehydrogenase system (MDH). As shown in figure 3, one monomorphic locus of Sinapis arvensis with the lowest mobility was always different from the corresponding locus in garden and wild radishes. For this locus, the wild radish showed an allelic polymorphism that allows $R$. raphanistrum to be sometimes distinguished from $R$. sativus, but some alleles had the same

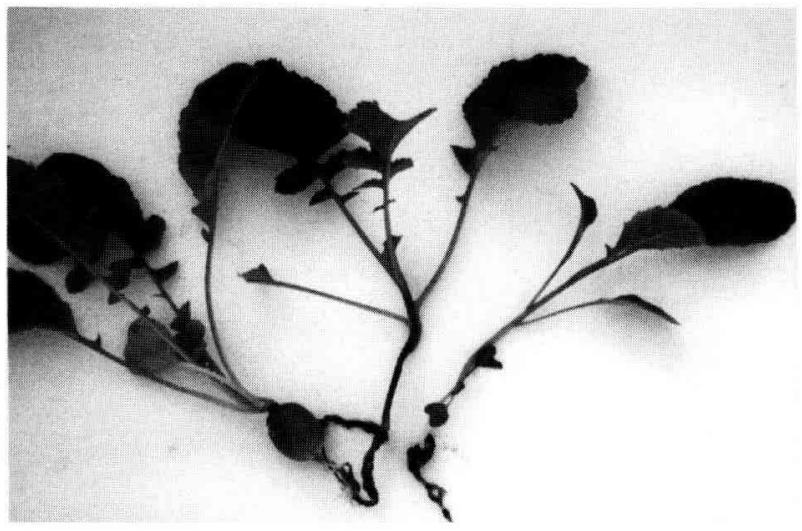

Figure 2. Morphology of a garden radish on the left, of an interspecific RsSar hybrid in the middle and of a wild mustard on the right.

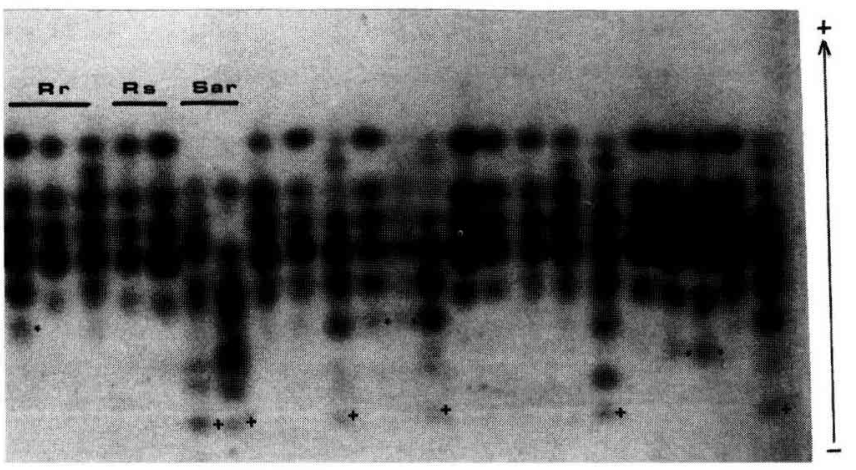

Figure 3. MDH zymograms of wild radish ( $\mathrm{Rr}$ ), garden radish (Rs), wild mustard (Sar) and of the different plants obtained from seeds harvested on male sterile garden radish (trial la). The wild radish allele which allows us to distinguish between wild and garden radish is indicated by ${ }^{*}$ and the specific wild mustard locus is indicated by + . mobility in these two species. Isozyme analyses using MDH system were performed on a total of 576 plants (259 from trial $1 \mathrm{a}$ and 317 from trial $1 \mathrm{~b})$. The results are reported in table $I I$. Interspecific hybrids (47 plants) between $R$. sativus and $S$. arvensis (RsSar) were identified and three of them had a swollen root. Among the $170 R$. sativus $-R$. raphanistrum hybrids (RsRr) identified, 94 plants had a swollen root. Among the 359 plants showing a RsRs MDH profile, 96 had abnormal root development.

\subsection{Cytogenetical control}

The mean meiotic behaviour of plants with and without a swollen root and with the three possible $\mathrm{MDH}$ profiles (RsRs, RsRr, RsSar) is given in table III.

Among the 47 plants identified as putative RsSar hybrids from the two criteria (morphological character and MDH profiles) (table II), 19 plants were chosen. As expected, among the 18 plants without swollen roots and with the $S$. arvensis MDH specific locus, 15 had 18 chromosomes and a disturbed meiotic behaviour, characteristic of an interspecific hybrid (univalent number ranging from 6 to 18) (figure 4A, table III). The three remaining plants had 27 chromosomes with a bivalent number ranging from 7 to 9 (table III). This triploid genomic structure was certainly due to unreduced gametes produced either by the female garden radish or by male wild mustard. One plant

Table II. Characterisation of plants obtained from the seeds harvested on the male sterile garden radish line in the 1a (259 plants) and $1 \mathrm{~b}$ (317 plants) trials.

\begin{tabular}{lccc}
\hline Swollen root & \multicolumn{3}{c}{ Isozyme characterisation } \\
& RsSar & RsRr & RsRs \\
\hline- & 44 & 76 & 96 \\
+ & 3 & 94 & 263 \\
\hline
\end{tabular}

Rs: garden radish genome; Sar: wild mustard genome; Rr: wild radish genome; -: plants without swollen root; +: plants with swollen root. 
Table III. Mean meiotic behaviour, from which the genomic structure was deduced, of representative plants characterised by the presence or the absence of swollen root (first criterion) and MDH allelic mobility (second criterion). The hybrids between garden radish and wild mustard are indicated in bold characters.

\begin{tabular}{|c|c|c|c|c|c|c|c|c|c|}
\hline $\begin{array}{l}\text { Swollen } \\
\text { root }\end{array}$ & $\begin{array}{c}\text { MDH } \\
\text { Allelic } \\
\text { Structures }\end{array}$ & $\begin{array}{l}\text { Genomic } \\
\text { structure }\end{array}$ & $\begin{array}{c}\text { Number } \\
\text { of } \\
\text { plants }\end{array}$ & $2 n$ & $\begin{array}{c}\text { Number } \\
\text { of cells } \\
\text { observed }\end{array}$ & Univalents & Bivalents & Trivalents & Quadrivalents \\
\hline - & RsSar & RsSar & 15 & 18 & 251 & $\begin{array}{c}11.90 \\
(6-18)^{*}\end{array}$ & $\begin{array}{c}3.04 \\
(0-6)\end{array}$ & $\begin{array}{l}0.004 \\
(0-1)\end{array}$ & \\
\hline+ & RsSar & RsSar & 1 & 18 & 15 & $\begin{array}{c}10.40 \\
(6-12)\end{array}$ & $\begin{array}{c}3.80 \\
(3-6)\end{array}$ & & \\
\hline- & RsRs & $\mathrm{Rs} \mathrm{Rr}$ & 3 & 18 & 47 & $\begin{array}{c}0.50 \\
(0-1)\end{array}$ & $\begin{array}{c}7.70 \\
(6-9)\end{array}$ & $\begin{array}{c}0.40 \\
(0-1)\end{array}$ & $\begin{array}{c}0.23 \\
(0-1)\end{array}$ \\
\hline- & $\mathrm{RsRr}$ & $\mathrm{RsRr}$ & 3 & 18 & 43 & $\begin{array}{c}0.65 \\
(0-1)\end{array}$ & $\begin{array}{c}7.56 \\
(7-9)\end{array}$ & $\begin{array}{c}0.65 \\
(0-1)\end{array}$ & $\begin{array}{c}0.07 \\
(0-1)\end{array}$ \\
\hline+ & RsRr & RsRr & 3 & 18 & 59 & $\begin{array}{c}0.41 \\
(0-2)\end{array}$ & $\begin{array}{l}8.56 \\
(7-9)\end{array}$ & $\begin{array}{c}0.13 \\
(0-1)\end{array}$ & $\begin{array}{c}0.02 \\
(0-1)\end{array}$ \\
\hline+ & RsRs & RsRs & 6 & 18 & 94 & $\begin{array}{c}0.04 \\
(0-2)\end{array}$ & $\begin{array}{c}8.98 \\
(8-9)\end{array}$ & & \\
\hline - & RsSar & $\begin{array}{c}\text { RsRsSar } \\
\text { or } \\
\text { RsSarSar }\end{array}$ & 3 & 27 & 33 & $\begin{array}{c}9.98 \\
(9-13)\end{array}$ & $\begin{array}{c}8.51 \\
(7-9)\end{array}$ & & \\
\hline - & RsRs & $\begin{array}{l}\text { RsRsRr } \\
\text { or } \\
\text { RsRrRr }\end{array}$ & 1 & 27 & 10 & $\begin{array}{c}9.10 \\
(7-11)\end{array}$ & $\begin{array}{c}8.80 \\
(8-10)\end{array}$ & $\begin{array}{c}0.10 \\
(0-1)\end{array}$ & \\
\hline
\end{tabular}

-: plants without swollen root; +: plants with swollen root; *: range values; Rs: garden radish genome; Rr: wild radish genome; Sar: wild mustard genome.
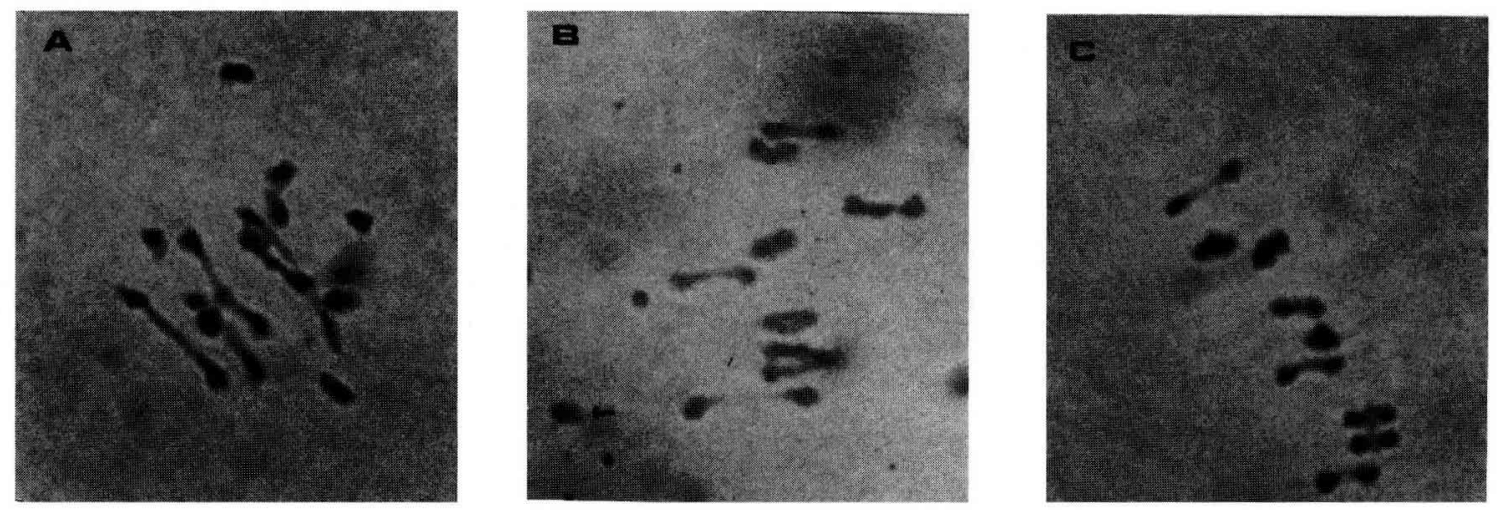

Figure 4. Metaphase I of pollen mother cells: a garden radish-wild mustard hybrid with 8 univalents +5 bivalents (A), a garden radish-wild radish hybrid with 1 univalent $(\leftarrow)+7$ bivalents +1 trivalent $(B)$ and a garden radish plant with 9 bivalents (C). 
with a swollen root but with MDH specific allele of $S$. arvensis was a garden radish-wild mustard interspecific hybrid (table III).

Among the 170 plants identified as putative RsRr hybrids from the two criteria (morphological character and MDH profiles) (table $I I$ ), six plants were selected. The three plants with swollen roots and the three plants without were confirmed to be interspecific hybrids between the two radish species by the presence of multivalents figure $4 B$, table $I I I)$ as previously described by Panetsos and Baker [9] and Eber et al. [4].

Among the 96 plants identified without swollen roots but with a RsRs MDH profile (table II), four plants were observed and were determined as garden radish-wild radish hybrids through cytogenetical analyses (table III). One of them had $2 n=27$ chromosomes. As for the garden radish-wild mustard plant already described, it was not possible to know the parent involved in the production of the unreduced gamete.

However, six of the plants, among the 263 with a normal hypocotyl development and a RsRs MDH profile (table $I I$ ), had a regular meiotic behaviour, similar to that of a normal garden radish, i.e. close to nine bivalents (figure $4 C$, table III).

\subsection{Hybridisation rates}

The hybridisation rates were calculated by taking into account two factors: the percentage of seeds in each grading group calculated from the weight percentage and the 1000 seed weight of each size group, the hybrid number according to MDH analyses in each category (table $I V$ ).

In the 1a trial, the largest group was formed by the bigger seeds. If the commercial seed size $(2.4<$ seeds $<2.8 \mathrm{~mm}$ ) was well represented in the $1 \mathrm{~b}$ trial with the radish pollinator, it was very low in the 1a trial. In the 1a trial, the smaller seeds were the least frequent, whereas they represented $27.8 \%$ of the whole harvest in the $1 \mathrm{~b}$ trial.

In the la trial, regardless of the seed size group, RsSar hybrids were identified. In this trial, without pollen competition, of 1000 seeds harvested, 42 were RsSar hybrids, i.e. 15, 13 and 14 RsSar hybrids from the biggest, the commercial and the smallest seed size groups, respectively. In the $1 b$ trial, it is only in the smallest seeds that this type of hybrid could be found, with three RsSar hybrids per 1000 seeds harvested.

Garden radish-wild radish hybrids were observed in all the seed size groups in the two trials. In the 1 a trial, they were more numerous

Table IV. Hybridisation rates calculated from the percentage of seeds and the number of hybrids identified by MDH analyses in each grading group in the $1 \mathrm{a}$ and $1 \mathrm{~b}$ trials.

\begin{tabular}{|c|c|c|c|c|c|c|c|c|c|}
\hline \multirow[b]{2}{*}{ Trials } & \multicolumn{2}{|c|}{ Sieving } & \multicolumn{3}{|c|}{ MDH analyses } & \multicolumn{4}{|c|}{ Hybridization rates } \\
\hline & Seed size & $\begin{array}{l}\% \text { of } \\
\text { seeds }\end{array}$ & $\begin{array}{c}\text { no. of } \\
\text { plants } \\
\text { obs. }\end{array}$ & $\begin{array}{c}\% \text { of } \\
\text { RsSar } \\
\text { hybrids }\end{array}$ & $\begin{array}{c}\% \text { of } \\
\text { RsRr } \\
\text { hybrids }\end{array}$ & $\begin{array}{r}\text { RsSar } \\
\text { no. seeds/ } \\
1000 \text { flow. }\end{array}$ & $\begin{array}{l}\text { hybrids } \\
\text { no. seeds/ } \\
\text { plant }\end{array}$ & $\begin{array}{r}\text { RsRr } \\
\text { no. seeds/ } \\
1000 \text { flow. }\end{array}$ & $\begin{array}{l}\text { hybrids } \\
\text { no. seeds/ } \\
\text { plant }\end{array}$ \\
\hline \multirow{3}{*}{ la } & seeds $>2.8 \mathrm{~mm}$ & 81.89 & 107 & 1.9 & 57.0 & 0.2 & 0.7 & 5.8 & 20.2 \\
\hline & $2.4<$ seeds $<2.8 \mathrm{~mm}$ & 15.27 & 80 & 8.7 & 48.7 & 0.2 & 0.6 & 0.9 & 3.2 \\
\hline & Seeds $<2.4 \mathrm{~mm}$ & 2.84 & 72 & 50.0 & 33.3 & 0.2 & 0.6 & 0.1 & 0.4 \\
\hline \multirow{3}{*}{$1 b$} & seeds $>2.8 \mathrm{~mm}$ & 18.35 & 79 & 0 & 8.9 & 0 & 0 & 20.9 & 21.9 \\
\hline & $2.4<$ seeds $<2.8 \mathrm{~mm}$ & 53.87 & 80 & 0 & 15.3 & 0 & 0 & 104.0 & 108.8 \\
\hline & seeds $<2.4 \mathrm{~mm}$ & 27.78 & 158 & 1.3 & 17.1 & 4.5 & 4.7 & 61.1 & 63.9 \\
\hline
\end{tabular}

Rs: garden radish genome; Sar: wild mustard genome; Rr: wild radish genome. 
among the biggest seeds, whereas in the $1 \mathrm{~b}$ trial they were mostly observed in the commercial grading group. Overall, we assessed that 551 and 144 RsRr hybrids among 1000 seeds were present in trials $1 \mathrm{a}$ and $1 \mathrm{~b}$, respectively.

\section{DISCUSSION}

We have demonstrated that substantial crop-weed hybridisation can occur between male sterile garden radish and wild mustard and that the risk of seed contamination by wild radish pollination is high when producing Fl hybrid garden radish seeds when the two weeds are close by.

In our study, in the two trials, there was an overlapping flowering period of the radish and the wild mustard. In the $1 \mathrm{~b}$ trial, the female male sterile line flowered 9 days before the male fertile line. That is to say that for 9 days there was no pollen competition and that during this period the female parent was in the same condition as the one in the la trial. This might explain the presence of RsSar interspecific hybrids in the $1 \mathrm{~b}$ trial. This demonstrates the importance of flowering period synchronisation between the male and the female lines.

Until now, the purity of commercial garden radish seeds was assessed from morphological observations of the plants obtained. In the present study, we have shown that, by this method, the interspecific hybrid number was under-estimated. The combined morphological, isozyme and cytogenetical observations revealed that some interspecific hybrids can show a garden radish morphology with a normal swollen root (normal in shape, size and colour).

Because of the high genetic similarity between the three species studied, only one isozyme system $(\mathrm{MDH})$ among the ten studied was efficient to discriminate garden radish-wild mustard hybrids. This was confirmed by cytological observation. Most of the hybrids showed the expected chromosome number, i.e. 18 chromosomes. Their meiotic behaviour revealed the presence of few multivalents whilst a number of univalents ranging from 6 to 18 were observed. Mizushima [7] described the meiotic behaviour of such hybrids with 1-2 bivalents. In our material, we have observed $0-6$ bivalents indicating that chromosome pairing either within each genome or between the two genomes can occur. However, the meiotic behaviour of the plants formed from unreduced gametes $(2 n=27)$ revealed that the homology between the genomes is low as no multivalent was formed.

The observation of garden radish-wild radish hybrids is explained by the presence of a few plants of $R$. raphanistrum growing under $200 \mathrm{~m}$ away from the fields. The high crossability between cultivated and wild radishes was previously described by Panetsos and Baker [9]. In fact, these two species are so close that they are now classified by some botanists as belonging to the same species [5]. Thus neither morphological observations nor isozyme analyses alone were efficient enough to assess the number of RsRr hybrids. The meiotic behaviour of the plants revealed that some hybrids can have the normal radish swollen root but also the MDH wild radish specific allele and reciprocally. This last observation was due to the fact that some $R$. raphanistrum allozymes have the same mobilities as those of $R$. sativus. However, if the morphological observations and the isozyme analyses are combined, underestimation of the interspecific hybridisation rates is reduced. The RsRr hybrid meiotic behaviour characterised by the presence of multivalents and few univalents was already described by Panetsos and Baker [9] and Eber et al [4].

The commercial size of the garden radish seeds is generally between 2.4 and $2.8 \mathrm{~mm}$, which is why three grading groups were obtained by sieving. These three seed size groups were also analysed to see whether the frequency of interspecific hybrids was different between the groups. Eber et al. [4] and Barranger et al. [1] reported that interspecific hybrids between oilseed rape (Brassica napus) and $R$. raphanistrum, had a smaller seed size than the parents. We observed in the $1 \mathrm{~b}$ trial, in the presence of the radish pollinator, that RsSar interspecific hybrids were identified only among the seeds with the smallest diameter. Although sieving seems efficient at preventing the commercialisation of RsSar interspecific hybrids, the hybrids between $R$. 
sativus and $R$. raphanistrum were present whatever the diameter of the seeds. Those observations demonstrate the importance of sieving but also of controlling the presence of wild radish around the production field. On the other hand, they indicate that if the probability of gene exchange from garden radish to wild mustard is low, gene flow can occur between the two species of radish.

Acknowledgements: This work was funded by a grant from the French Ministry of Agriculture: 'Évaluation et réduction des risques de pollution pollinique des productions de semences par les jachères'. J. Brace (Wellesbourne, UK), R. Delourme and M. Renard (Inra, Rennes, France) are gratefully acknowledged for their critical and helpful reading of the manuscript. We thank J.C. Letanneur for his technical assistance.

\section{REFERENCES}

[1] Baranger A., Chèvre A.M., Eber F., Renard M., Effect of oilseed rape genotype on the spontaneous hybridization rate with a weedy species: an assessment of transgene dispersal, Theor. Appl. Genet. 91 (1995) 956-963.

[2] Chèvre A.M., Delourme R., Eber F., Margalé E., Quiros C.F., Arus P., Genetic analysis and nomenclature for seven isozyme systems in Brassica nigra, B. oleracea and B. campestris, Plant Breed. 114 (1995) $473-480$.

[3] Chopinet R., Sur quelques hybrides expérimentaux interspécifiques et intergénériques chez les Crucifères, Compt. Rend. Acad. Sci. 215 (1942) 545-547.
[4] Eber F., Chèvre A.M., Baranger A., Vallée P., Tanguy X., Renard M., Spontaneous hybridization between a male sterile oilseed rape and two weeds, Theor. Appl. Genet. 88 (1994) 362-368.

[5] Jauzein P., Flore des champs cultivés, Inra Ed., Paris, 1995.

[6] Klinger T., Arriola P.E., Ellstrand N.C., Cropweed hybridization in radish (Raphanus sativus): effects of distance and population size, Am. J. Botany 79 (12) (1992) 1431-1435.

[7] Mizushima U., Genome analysis in Brassica and allied Genera, in: Tsunoda S., Hinata K., Gomez-Campo C. (Eds.), Brassica Crops and Wild allies. Biology and Breeding, Japan Scient. Soc. Press, Tokyo, 1980, pp. 89-108.

[8] Ogura H., Studies on the new male sterility in japanese radish, with special references to the utilization of this sterility towards the practical raising of hybrid seeds, Mem. Fac. Agric. Kagoshima Univ. 6 (2) (1968) 39-78.

[9] Panetsos C.A., Baker H., The origin of variation in 'wild' Raphanus sativus in California, Genetica 38 (1967) 243-274.

[10] Shields C.R., Orton T.J., Stuber C.W., An outline of general resource needs and procedures for the electrophoresis separation of active enzymes from plant tissue, in: Tanksley S.D., Orton T.J. (Eds.), Isozymes in Plant Genetics and Breeding, Part A, Elsevier Science Publishers B.V., Amsterdam, 1983, pp. 443-468.

[11] Turesson G., Nordenskiold, Chromosome doubling and cross combinations in some cruciferous plants, The Annals of Agricultural College of Sweden 11 (1943) 201-206.

[12] Vallejos C.E., Enzyme activity staining, in: Tanksley S.D., Orton T.J. (Eds.), Isozymes in Plant Genetics and Breeding, Part A, Elsevier Science Publishers B.V., Amsterdam, 1983, pp. 469-516. 